\title{
ラット実騟的水頭症の髄液循環路
}

\author{
小竹 源也・山木 重水・成瀬 昭二
}

\section{CSF-Circulation Pathways in Experimental Hydrocephalus of the Rat}

\author{
Genya Odake, Tarumi Yamaki and Shoji Naruse \\ Department of Neurosurgery, Kyoto Prefectural University of Medicine
}

\begin{abstract}
Summary
Experimental hydrocephalus of the rat was produced by cisternal injection of Kaolin-solution. Intraventricular injection of India ink disclosed obstruction of cerebrospinal fluid pathways at the tentorial incisura in the hydrocephalic rat, while the same injection to the normal rat showed diffuse spreading of the dye over whole subarachnoid space of the brain. The injection of the dye into the cerebral subarachnoid space showed obstruction of the dye at the tentorial incisura in the hydrocephalic rat, while sufficient communication was observed between supratentorial and infratentorial subarachnoid spaces in the normal rat. There were however no remarkable differences between the normal and the abnormal rats about distribution of India ink over the cerebrum under macroscopic and microscopic observations.

Obstruction at the tentorial incisura was caused by arachnoid fibrosis and granulation and not by tentorial herniation. Considering experimental findings of paucity of adhesive arachnoiditis over the cerebrum and clinical reports of reversibility of the cerebral subarachnoid space, much effort should be made to promote CSF absorption over the cerebrum, instead of external drainage.
\end{abstract}

Key words : hydrocephalus, cerebrospinal fluid pathways, India ink, tentorial incisura, supratentorial subarachnoid space

\section{I はじめに}

Dandy とBlackfan ${ }^{32}$ 以来，実験動物に後天的水頭症を 作成する試みが多数報告されてきた。我々は小型動物で あるラットの大槽内にカオリン溶液を注入して，交通性 水頭症を作成し，拉大した䏲室に墨汁を注入したとこ ろ，墨汁は小脳半球表面に应散するが，天幕切痕部を越 えず大畄半球表面に至らないことを報告しだ，今回， 我々はこの墨汁の㹡散状態と組織学的闭見について報告 するとともに，水頭症におけるクモ膜下胫の可逆性につ いて検討した。
II方法

生後 $5 \sim 6$ 週, 体重 $150 \sim 200 \mathrm{gr}$ のラットの大槽内に カオリン溶液 $0.05 \sim 0.1 \mathrm{ml}$ を注入し，4 週閒後すなわち 水頭症がすでに報告したように，外見上著明な時期に脳 定位的に27グージの針を冠状縫合加ら尾側 $2 \mathrm{~mm}$ ，矢状 繾合から側方 $1 \mathrm{~mm}$ で刺入し，深さ $3 \mathrm{~mm}$ で側脳室内 一墨汁 $0.05 \sim 0.1 \mathrm{~m} l$ を 注入した群と天幕上大媨半球表 面クモ膜下腔に同量の鲑汁を注入した群を作り，さらに 同様な操作を加えた正常ラットの二群も作った。

これらラットは壘汁注入後, 大多数は30分以内に，上 きには数時間ないし一週間以内に麻酔下に中性楥衝木ル

京都府立医科大学这神経外科

【連絡先： 个602 京都市上京区河原町通り広小路上ル梶井町 465, 京都府立医科大学脳神経外科，小竹源也〕 1978年 3 月 22 日 受稿 
マリン溶液の左心窒内注入による脳灌流固定をらけた。 むろん罟汁注入を受けない正常招上び水頭症ラットも対 照として脳灌流固定をらけた．灌流後ラットの脳はただ ちとクモ膜を賃つけない上う一部硬膜をつけたま頭蓋 骨より取りはずされ，脳表の墨汁の拡散状態の検討に供 された, 前額断に上り, 脳室内の罢汁の拡散状態の検討に 供された上で, 組織標本の作成に使われたものむるる。

\section{III 結 果}

\section{1. 睬室内注入}

墨汁の側船室内注入により，正常ラットの背側では墨 汁は第 4 腷室孔を出て小脳半球表面化搪散し, cerebellar cistern から ambient cistern 抒よび quadrigeminal cistern を一下大脳半球表面招上び半球間のクモ膜下腔に至 る稀路を取り，腹側ではcerebellomedullary cistern, cerebellopontine cistern, prepontine cistern, interpeduncular cistern と進んで, ここから chiasmatic cistern, Sylvian cistern あるいは olfactory cistern k到達し，さらに大媨 表面汇至る。一部忹 interpeduncular cistern より ambient cistern 等天幕切痕周囲に至る. 墨汁注入では加圧されて 拉り，正常な流れを知ることは困難である。しかしいず

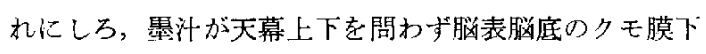
腔を自由に摭散する (Fig. 1 A, B).

水頭症ラットでは墨汁は cisterna magna より小譄半 球表面 cerebellar cistern に拡散し，さらに ambient cistern 抢よび quadrigerninal cistern に至るが，大这半球表

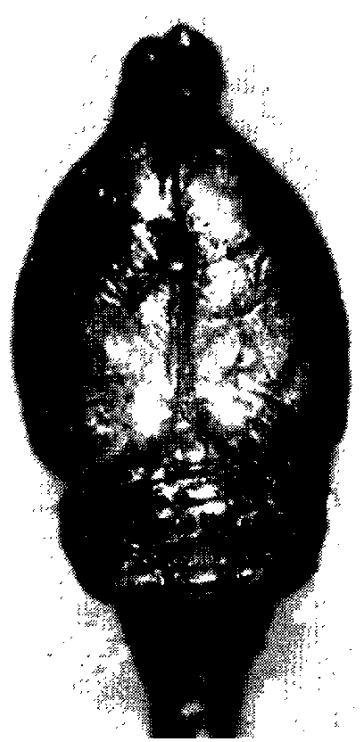

A
面および半球間のクモ膜下腔には去ったく到達しない， 腷底では狭小となった cerebellomedullary cistern, cerebellopontine cistern, prepontine cistern, interpeduncular cistern, crural cistern を経て天幕切痕周囲のクモ膜下腔 に至るが，檤底の前部すなわち chiasmatic cistern，Sylvian cistern, olfactory cistern にはほとんど到详できな い(Fig. $2 \mathrm{~A}, \mathrm{~B}$ ).

\section{2. 大脳半球クモ膜下注入}

しかしながら水頭症ラットに扔いて侧脳室内への墨汁 注入に失敗した，すなわら脳実質表層内に畦汁が注入さ れた場合には壘汁は脳室内に穿破せず，大脳半球表面の クモ膜ト腔に㹡散し，脳底部にはわずかにしか進入甘 ず，天幕切痕部で完全に遮断され，小腷半球表面に注ま ったく畦汁を見ることができなかった。 そこで意図的に 大脳半球表面のクモ膜下腔に罡汁注入を行ったが, 結果 は同じであった（Fig. 3 A,B)。

一方正常ラットの大媨半球表面のクモ膜下腔比量汁を 注入した場合には，墨汁汢大脳半球表面に搪散し，脳底 にも到達し，天幕切痕部を越えて小脳半球表面に抬散し た (Fig. $4 \mathrm{~A}, \mathrm{~B}$ ).

\section{3. 組織学的所見}

光瀕的に水頭症ラットを調べると，脳室の拡大，脳室

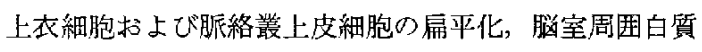
の浮腫がみられた．正常ラットのクモ膜下には，粗な結 合織の索が誌められるのみであり，カオリンに上る水頭 症ラットに招いても大脳表面のクモ膜下脭はやや狭いだ

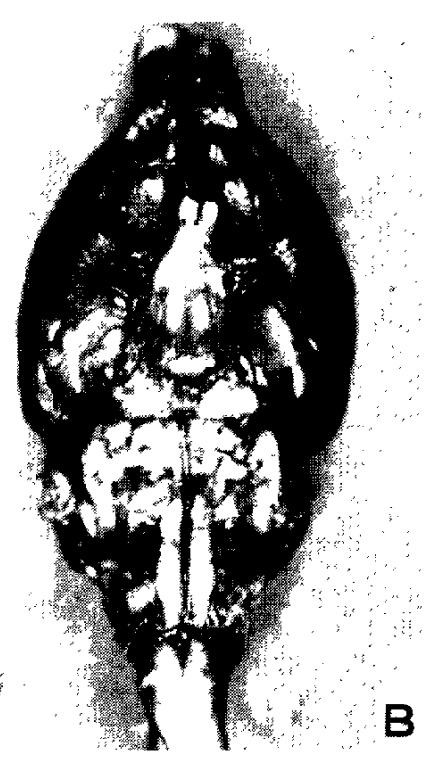

Fig. 1 Intraventricular injection of India ink to a normal rat. Dorsal (A) and ventral (B) subarachnoid spaces of the brain and the spinal cord are filled with the dye. 

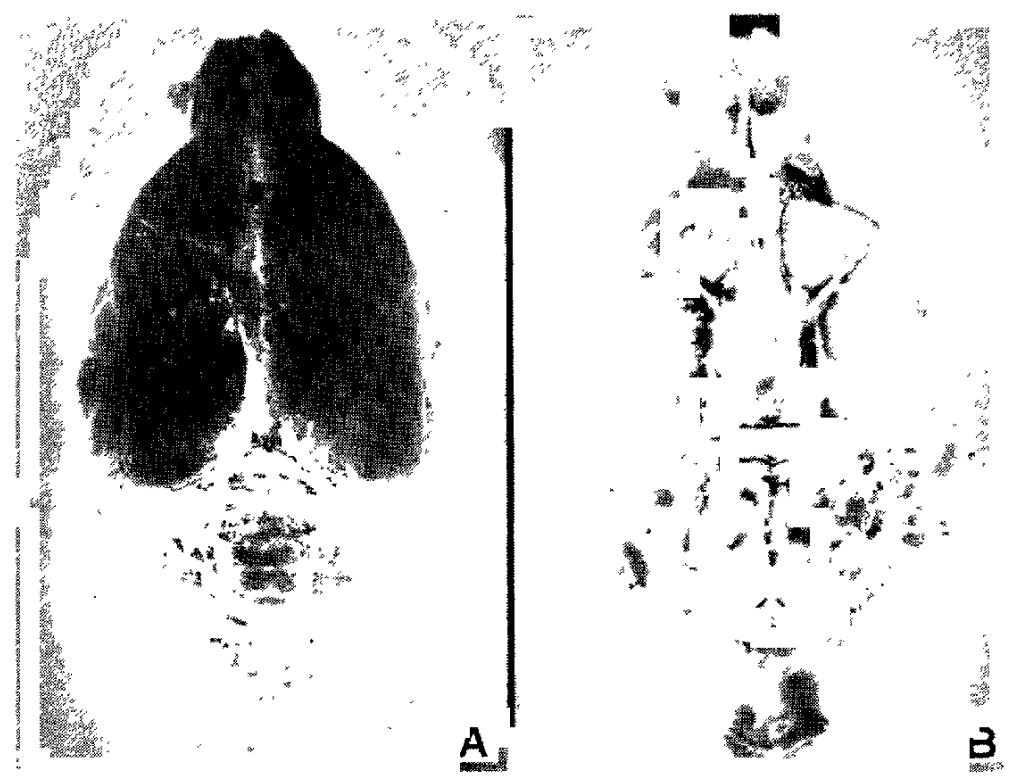

Fig. 2 Intraventricular injection of Indıa ink to a hydrocephalic rat. Dorsal (A) and ventral (B) subarachnoid spaces of the cerebrum are devord of the dye despite its filling of the infratentorial space.
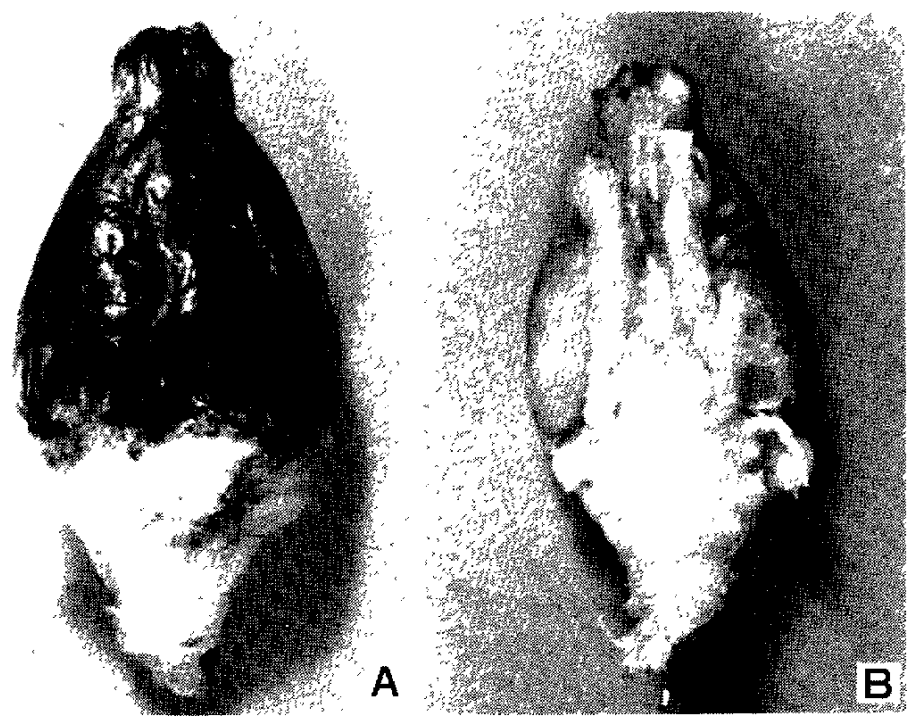

Fig. 3 Supratentorial subarachnoid injection of India ink to a hydrocephalic rat. Dorsal subarachnoid space of the brain (A) is filled with the dye, but ventral subarachnoid space of the cerebrum and infratentorial subarachnoid space is lacking the dyc.

けで，結合織の增殖，紐胞浸潤等の炎症反応は見出せ ず，クモ膜下腔の胃汁注入に括いて子正常ラット上の間 に有意な差を認めえなかった〈Fig. 5 \}。しかし水頭症う ットの脳底には高度の肉芽組織が生じて㧍り，カオリン 顆粒の集合した部ではクモ膜下腔はまったく閉塞してい
た（Fig．6)，一般に媨底正中部に打いてこのような変化 が強く, 脳底両側方部ではわずかなクモ膜下腔の開存を しばしば認めた。両侧の ambient cistern の下端では, 譄 底から連続的に肉芽組織が脳幹部上側頭葉の間に侵入し ているが、これは下半部までで，天幕切痕部全周に扝よ 

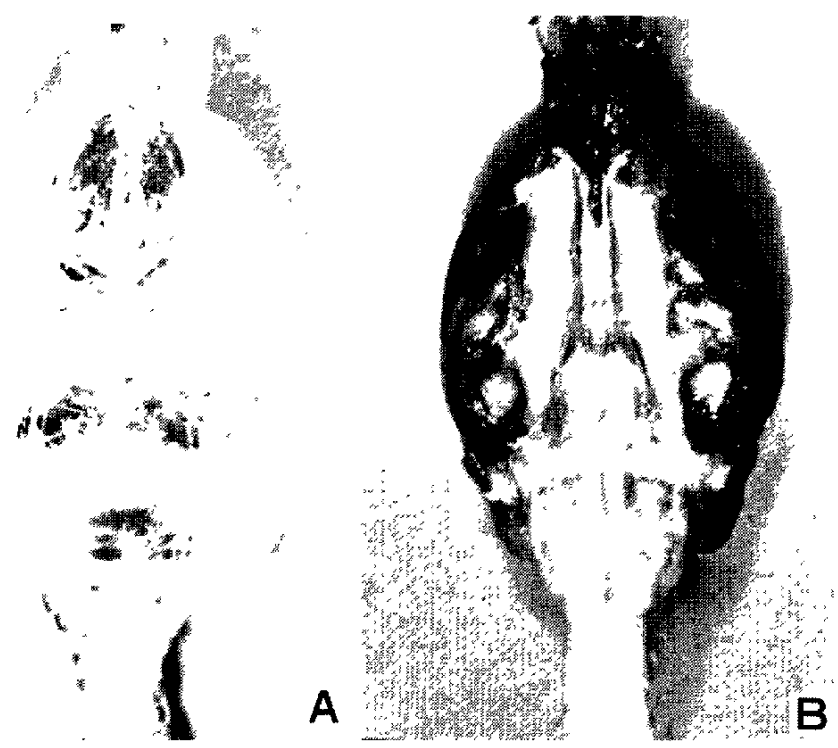

Fig. 4 Supratentorial subarachnoid injection of India ink to a normal rat. Dorsal subarachnoid space of the brain (A) is filled with the dye. The dye is barely noted in ventral subarachnoid space of the brain (B). Spinal arachnoid membrane was teared off unfortunately. Note filling of the dye into the cerebellar subarachnoid space.
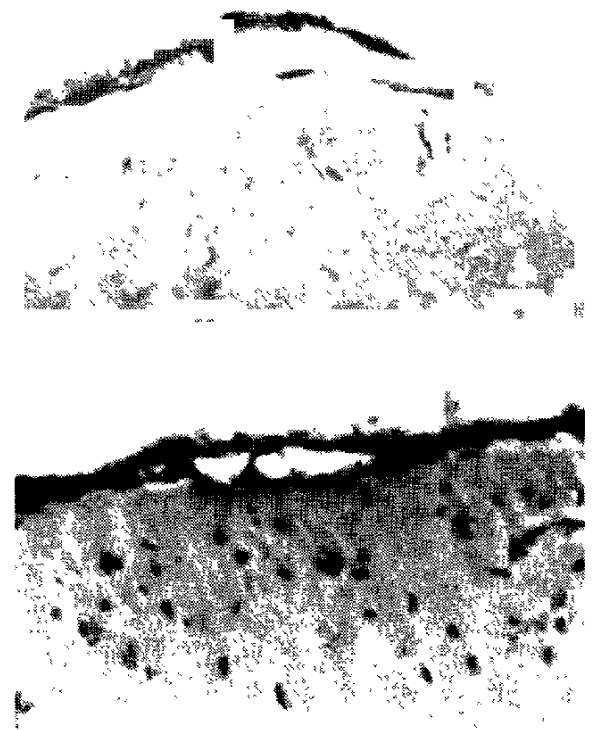

Fig. 5 A normal (A) and a hydrocephalic (B) supratentorial subarachnoid spaces of rats are equally filled with the India ink.

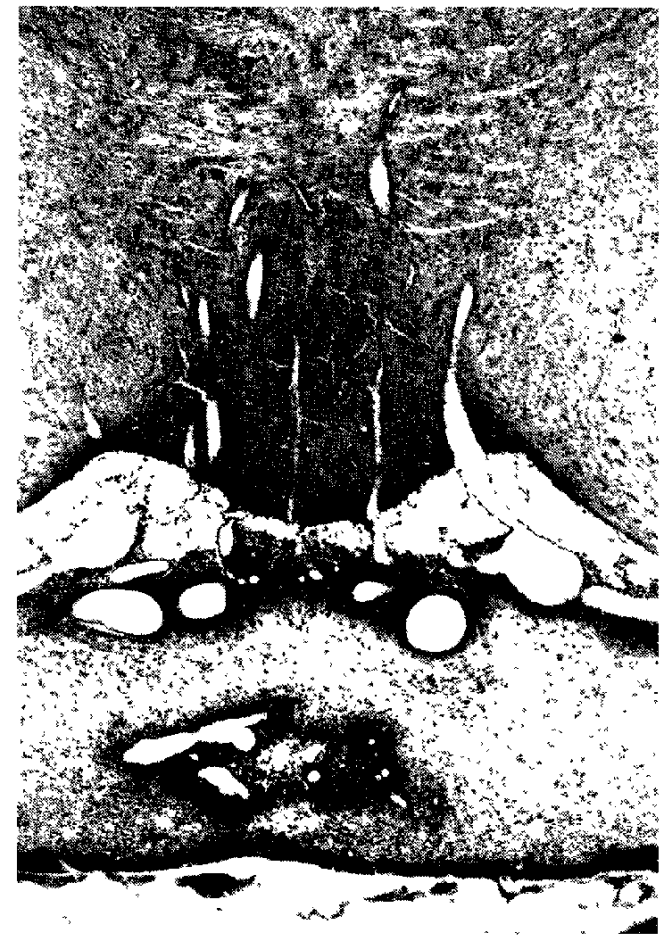

Fig. 6 Arachnoid granuloma constricts subarachnoid space at the base of the brain stem of a hydrocephalic rat. 


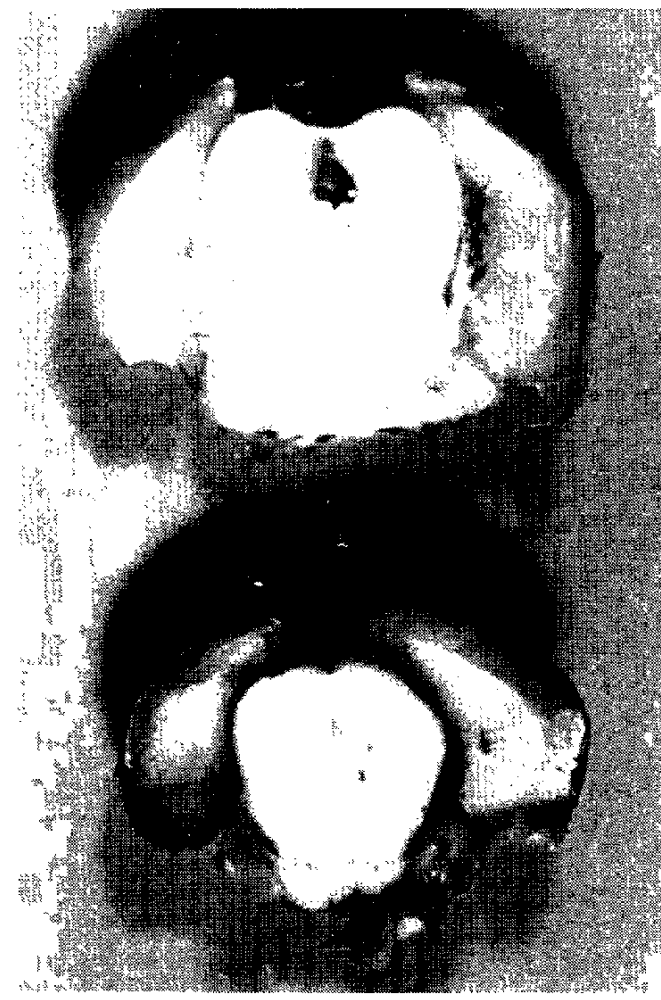

Fig. 7 Subarachnoid space between the brain stem and the temporal lobe of a hydrocephalic (upper) and a normal (lower) rat. Note intense granulation of this space in the hydrocephalic rat.
ぶことは見られなかった（Fig，7）。ただし上部の ambient cistern, quadrigemial cistern においても不連続的肉 牙の增殖が認められ，クモ膜下腔はかえって应大してい た (Fig. 8 A, B). Ambient cistern の下部俚正常ラット では脑幹と側頭葉の問の狭い閒渻であるが，水頭症ラッ トで沬著しく拉大し，肉芽組織の増殖に伴い無数の毛細 血管の新生が見られた（Fig，9A，B），そして側檤室に注 入された悬汁は正常ラットの側頭葉と㗖幹の間に線状に 侵入するが，水頭症ラットでは外見上と異なってまった く侵入していない。

\section{IV 考察}

カオリンによる水頭症の成立は，譄庭のカオリン顆粒 を中心とした高度のクモ膜線維症によ万畄底随液路の狭 窟ないし閉塞が天幕切痕周囲におよんだためと考えら れ，我々の前回の報告 ${ }^{17}$ でる明らかなよらに交通性水頭 症である、ここで水頭症のタイプを交通性と非交通性 ${ }^{2)}$ 閉塞性と非閉塞性 ${ }^{15)}$ という二つの異なったカテゴリーに

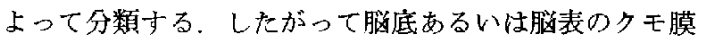
下腔閉塞によるすのは, 交通性, 中脳水道等の脳室系の閉 塞のものは非交通性であり，閉塞性はこれらすぶての㖪 液路のいずれかにおいて閉塞されたものを総括し, 非閉 塞性は娟液産生過剩, 頭蓋静脈洞閉塞症に上る䯣液吸収 障害等によるすのを意味することを認識した上で，種々

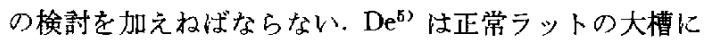
フェロシアン化カリウムとクェン酸鉄アンモ二ウム溶液
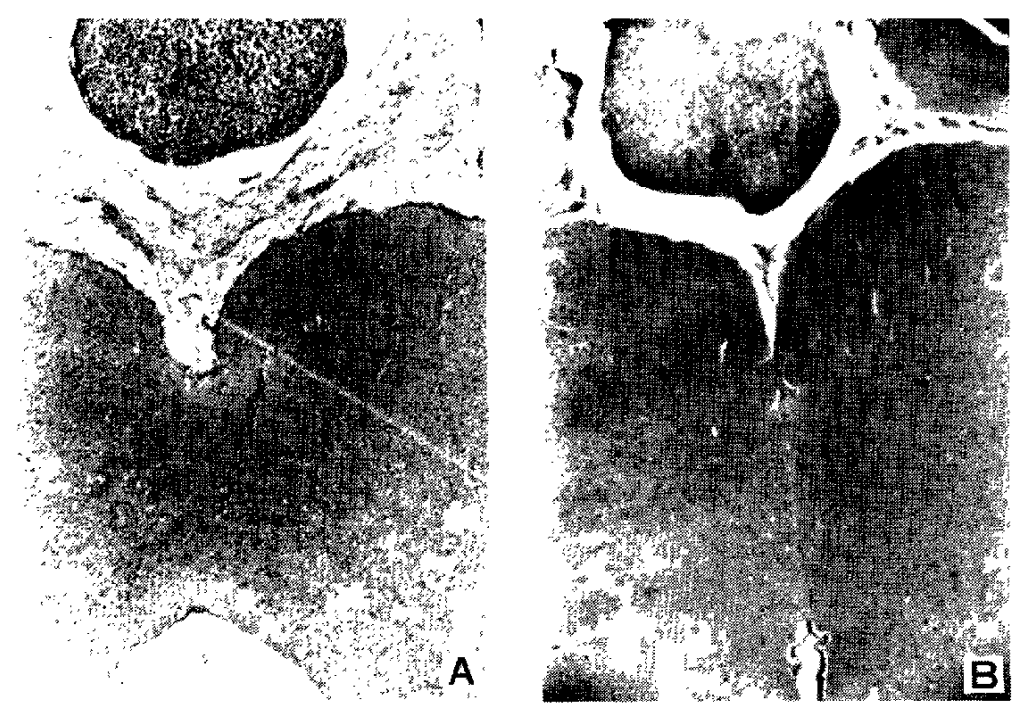

Fig. 8 Arachnoid fibrosis of a hydrocephalic rat (A) and scanty arachnoid of a normal rat (B) at the level of the quadrigeminal plate. The dilated aqueduct in the former is seen. 

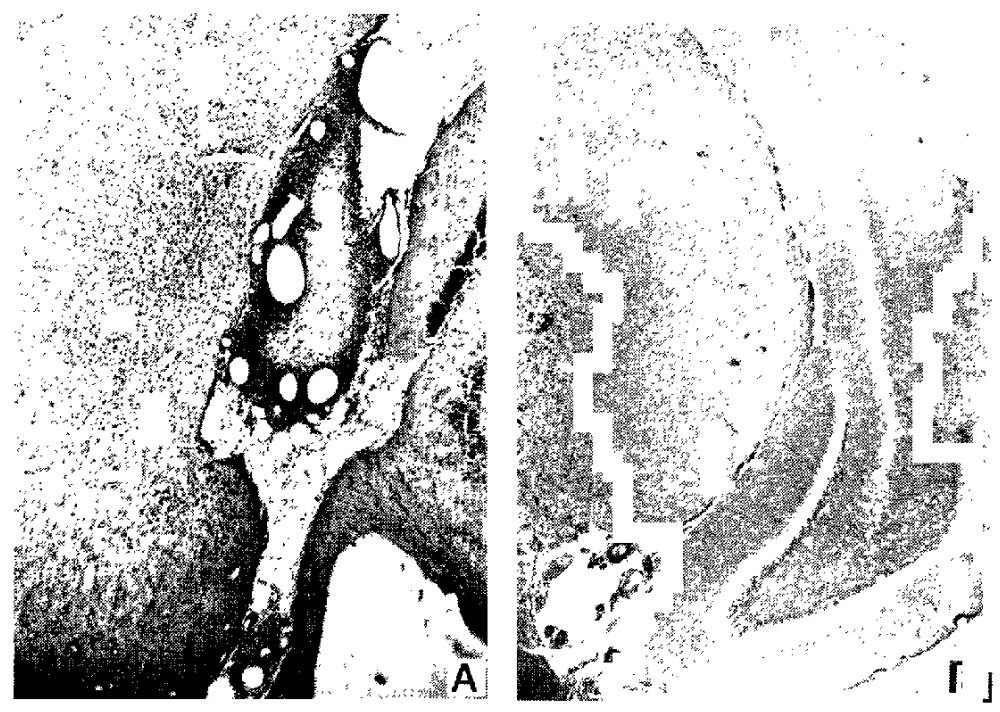

Fig. 9 Microscopic observations of the subarachnoid space bctween the brain stem and the hippocampus of a hydrocephalic $(A)$ and a normal rat $(B)$. Note widening and intense granulation of the space of the hydrocephalic rat.

在注入し，プロシアンブルー反応で，また Milhorat ${ }^{8)}$ は 正常サルの譄室内にエバンスブルーを注入してこれら 色素がただちに脳表全体に拉がることを示している。 れ汢我々の正常ラットに打りる墨汁の側媨宾内注入军験 の結果と一敨している。このように正常ラットでは天幕 下加ら天幕上人クモ膜下腔を色素が自由に拉散すること は明らかであり，加压の影響を考慮しなければならない が，天幕上から天幕下人も色素が自由に拉散し5ること を知った。一方第 4 脑室をバルーンで閉塞して作成した 非交通性の閉塞性水頭症サルの大槽内に，フェノールス ルフォフタレンを注入したMilhorat" の塞験でむ，先天 性水頭症マウ又 (一期) hy $-3 /$ hy -3 の側脳室内に卜y パンブルーを注入した Raimondi ${ }^{13) 14)}$ の奉験でも，交通 性の閉塞性水頭症ラットの㑡媨室内に罍汁を注入した我 々の奏験でる，色素住小腷半球表面に拉散寸るが，天幕 切痕部で停止し，大这半球表面に恃およばなかった。こ

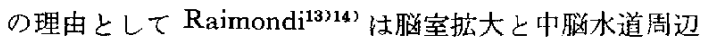
部の浮腫を挙げており、Milhorat ${ }^{72}$ 虹側頭葉の天幕切痕 八の陥入と脳回の扁平化，圧迫による天幕上夕モ膜下腔 の閉塞を挙げている. Milhorat ${ }^{7)}$ 江自然発生交通性水頭 症イ又の側腷室内に色素支注入し，天幕切痕部に拟て 色素が停止するの牧びまん性，非特異的な大媨半球の髄 膜炎によるとも述ぺている。我々の水頭症ラットだは crural-, interpeduncular-, ambient-, quadrigcminal cistern において強い癒着示示肉芽組織・クモ膜の増 殖があり，多数の新生血管を諗めたが，中脳と側頭葉の
間柗は应大し，天幕切痕へルニアの所見は認められなか $a k$ これらの所見から，我々は墨汁が天幕切痕部で停 滞するのは，はじめ狭い䀎液路であるこの部に壬膜肉 芽が脳底部より侵入し，粗な增殖夕モ膜に取り囲屯れた 多数の小さな䯚液貯溜腔圭作ったのち，胹庭部に近い部 分で肉来が密になり，この髄液路を閉塞すると考えた。 我々の水頭症ラット厄注縕織学的に与大脳半球表面のク モ膜下腔にはカリオン顆粒はまったく見出されず，間㩐 你くなっているが，獠着，肉芽等の閉塞性炎症反応は 見られず，また大脳半球表面りモ膜下腔への注入で墨汁 は天幕切痕部でさえぎられはするが，大脳半球表面に十 分桩散することから，このクモ膜下腔は水頭症すなわ ち脪室航大のために機械的に压迫されているだけで, Milhorat ${ }^{9310) 11>}$ の考慮している二次的な線維症や髄膜炎 による不可逆的脳表の閉塞は無く，単に機能不全の状態 にあると考えられる。したがって臨床例において，すな わらクモ膜下出血ある以注髄膜炎後発生してくる水頭症 の大多数においても，大脳表面における䯣液循環障 害 は，脳底き天幕切痕部に扣りる反店性の療着性クモ膜炎 に上る脳室拉大の結果生じてきた，二次的，機械的なも のではないかと考光られる。そして Milhorat"1010) は臨 床的に天幕切痕へルニア执よびそれにつすく basilar cistern の閉塞の原因と考える天幕上の䯙膜の線維症 が 不可逆的である証拪を示しえず，逆に脳室心房吻合不全 に执てRISA cisternography で示された basilar cistern での停滞が吻合再建後汢消失し，天幕上人应散した 
事実を報告し，さらに先天的水頭症52例に良く発達した

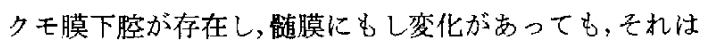
水頭症のタイプや閉塞巣の性格には関係がなく、むしろ 感染,クモ膜下出血の病歴のみならず水頭症の程度, 期間, 外科的手術の結果に関係していると報告している。この

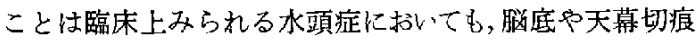
部のクモ膜下腔の閉塞が重要な意味を持ち, 天幕上のタ モ膜下腔は通路としての可逆性有する症例が多数存在 すると考えられる．水頭症の治療として現在多用されて

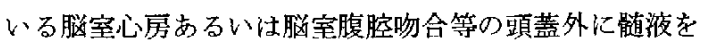
誘導する方法よりる，クモ膜顆粒の吸収能さえ低下して いなければ，脳室内跹液を天幕上の閉塞の無いクモ膜下 琁に誘導吸収させる方がはるかに合理的であり,Dandy" はすでに1922年に第 3 脑室から cisterna lamina terminalis へ咀液を誘導していたのである.1966年 Sayers ${ }^{16)}$ は，各々数回の䏚室心房吻合再建術要した先天性閉塞 性水頭症14例に対して第 3 腷室切開術を行い，10例にお いて好結果を得て扔り，また Patterson ${ }^{12)}$ は後天的閉塞 性水頭症に扔いてる同方法の佂值を再諗識している.De$\mathrm{Fe}^{6}$ ) はカオリンによる実験的水頭症イ邓11頭の大脳半 球に孔を穿ち，クモ膜顆粒に近いクモ膜下腔に侧脑室檤 液支直接誘導する方法考考案し，7頭に拈いて臨床症状 の劇的改善をみた。しかし Patterson ${ }^{12)}$ の不成功例にク モ膜下出血後の水頭症があり，症例選択に空気あるいは RISA cisternography の重要性が強調されていること，女 るいは先に述べたMilhorat" の症例において，RISAが 天幕上一搪散したにもかかわらず，Torkildsen 吻合が無 效であったことを考虑すると，我々の実䮖から天幕上の クモ膜下腔がいか比空間としての可逆性を有していて も,クモ膜顆粒そのものの吸収能についてはまったく判 らない. また RI cisternography において RI が大脳表 面に到達しても，そこで停滞する症例に扔いては腷室 拡大のため天幕上のクモ膜下腔は狭小となり，骮液循環

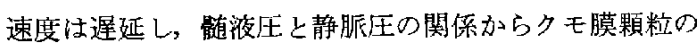
骮济吸収は当然低下しているから，これだけでクモ膜顆 粒そのものの吸收能が不可逆的に障害されているともい えず, RI cisternography やinfusion test だけから天幕上 クモ膜下腔の䯚液吸収能を簡単に推定するすけにはいか ない. したがって将来，クモ膜顆粒を含わていわゆる 末梢のクモ膜下腔の解剖学的あるいは吸收機 能面での ability 適確に知るための検查法を確立することが必要 であり，その時点に打いてはじわて頭蓋内ドレナージの 有効性が明らかになると考えられる。我々の㬰験注，ク 王膜顆粒そのものの髄液吸收能に関してはまったく解答 を与えないが，多くの人タが失望している水頡症の頭蓋
外ドレナージに代る何らかの新しい方法を求める試みの 一段階として役立てば良いと考える。

\section{文献}

1) Clark, R. G. \& Milhorat, T. H.: Experimental hydrocephalus Part 3. Light microscopic findings in acute and subacute hydrocephalus in the monkey. $J$ Neurosurg 32:400-413, 1970

2) Dandy, W. E. \& Blackfan, K. D. : An experimental and clinical study of internal hydrocephalus. JAMA 61: 2216-2217, 1913

3) Dandy, W. E. \& Blackran, K. D.: Internal hydrocephalus. An experimental, clinical and pathological study. Am J Dis Child 8: 406-482, 1914

4) Dandy, W. E.: An operative procedure for hydrocephalus. Bull Hopkins Hosp 33: 189-192, 1922

5) De, S. N.: A study of changes in the brain in experimental internal hydrocephalus. $J$ Pathol 62: 197-208, 1950

6) DeFeo, D., Foltz, E. \& Lederhaus, S.: Hydrocephalus: Possible role of an internal cerebrospinal fluid fistula in therapy. Surg Neurol 6: 271-274, 1976

7) Milhorat, T. H. \& Clark, R. G.: Some observations on the circulation of Phenolsulfonpthalein in cerebrospinal fluid: Normal flow and the flow in hydrocephalus. $J$ Neurosurg 32 : $522-528,1970$

8) Milmorat, T. H., Clark, R. G., Hammogk, M. K. \& McGrath, P. P.: Structural, ultrastructural, and permeability changes in the ependyma and surrounding brain favoring equilibration in progressive hydrocephalus. Arch Neurol 22: 397-407, 1970

9) Milhorat, T. H., Hammock, H. K. \& Di Chiro, G.: The subarachnoid space in congenital obstructive hydrocephalus Part 1: Cisternographic findings. $J$ Neurosurg 35: 1-6, 1971

10) Milhorat, T. H., Намmock, M. K. \& Chandra, R. S.: The subarachnoid space in congenital obstructive hydrocephalus Part 2: Microscopic findings. $J$ Neurosurg 35: 7-15, 1971

11) Milhorat, T. H.: Hydrocephalus and the cerebrospinal fluid. The Williams \& Wilkins, pp 118-121, 1972

12) Patterson, R. H., Jr. \& Bergland, R. M.: The selection of patients for third ventriculostomy based on experience with 33 operations. $J$ Neurosurg 29: 252-254, 1968

13) Raimondi, A. J., Bailey, O. T., Malone, D. G., Lawson, R. F. \& Echeverry, A.: The 
pathophysiology and morphology of murine hydrocephalus in $\mathrm{Hy}-3$ and $\mathrm{Ch}$ mutants. Surg Neurol 1: 50-55, 1973

14) Raimondi, A. J., Clark, S. J. \& Mcloe, D. G.: Pathogenesis of aqueductal occlusion in congenital murine hydrocephalus. $J$ Neurosurg 45 : 66-77, 1976

15) Russel, D. S.: Observations on the pathology of hydrocephalus. Special Report Series Medical Research Council, No. 265, London, 1949
16) Sayers, M. P.: Discussion. Treatment of hydrocephalus by operations not requiring mechanical tubes or valves, J.E. Scaff. p 74, In Shulman, K. (ed): Workshop in Hydrocephalus, University of Pennsylvania Press, Philadelphia, 1966

17) Yamaki, T., Odake, G. \& Naruse, S.: Experimental hydrocephalus of the rat, produced by cisternal injection of Kaolin-solution. Neurol Surg (Tokyo) 5: 537-540, 1977 